\title{
DOSE-DEPENDENT AND SPECIES-SPECIFIC RESPONSES OF PINE BARK BEETLES (COLEOPTERA: SCOLYTIDAE) TO MONOTERPENES IN ASSOCIATION WITH PHEROMONES
}

\author{
Daniel R Mille R' and John H Borden
}

Centre for Environmental Biology, Department of Biological Sciences, Simon Fraser University, Burnaby, British Columbia, Canada V5A 1S6

\begin{abstract}
The Canadian Entomologist 132: 183 - 195 (2000)

Monoterpenes affected the attraction of three sympatric species of bark beetles (Coleoptera: Scolytidae) to pheromone-baited multiple-funnel traps in stands of lodgepole pine. Catches of Ips pini (Say) in traps baited with its pheromone, ipsdienol, were directly related to the release rates of 3-carene, pphellandrene, and $\beta$-pinene. Catches of Dendroctonus ponderosae Hopkins in traps baited with exo-brevicomin and cis- and trans-verbenol were directly related to the release rates of 3-carene, myrcene, and $\beta$-phellandrene. Ips Zatidens (LeConte) exhibited preferences for traps baited with ipsenol and $\beta$-phellandrene or $\beta$-pinene but not in a dose-dependent fashion. Catches of I. latidens in traps baited with its pheromone, ipsenol, were inversely proportional to the release rates of 3-carene, myrcene, and terpinolene. Similarly, catches of $I$. pini in traps baited with its pheromone, ipsdienol, were inversely proportional to the release rates of myrcene and terpinolene. These results demonstrate a degree of species specificity among three phloeophagous species with respect to preferred host odours. The bark beetle predators-associates Lusconotus complex LeConte (Coleoptera: Colydiidae) and Corticeus Piller and Mitterpacher sp. (Coleoptera: Tenebrionidae) demonstrated some measure of specificity to monoterpenes in their responses to ipsdienol-baited funnel traps. y-Terpinene increased attraction of L. complex but had no effect on Corticeus sp., whereas a- and $\beta$-pinene increased attraction of Corticeus sp. but had no effect on $L$. complex.
\end{abstract}

Miller DR, Borden JH. 2000. Réactions spécifiques à la dose et à l'espèce chez des scolytes des pins (Coleoptera; Scolytidae) mis en présence de monoterpènes combinés à des phéromones. The Canadian Entomologist 132 : 183-195.

\section{Résumé}

La presence de monoterpbnes a modifié l'attirance de pièges à entonnoirs multiples garnis de pheromones pour trois espbces sympatriques de scolytes des pins (Coleoptera : Scolytidae) dans une for\&t de pins à feuilles tordues. Les récoltes d'Ips pini (Say) dans les pièges garnis de la pheromone même de l'insecte, l'ipsdienol, Ctaient reliées directement aux taux de liberation de 3 -carène, de $\beta$-pheilandrène et de $\beta$-pinène. Les récoltes de Dendroctonus ponderosae Hopkins dans les pièges garnis d'exo-brévicomine et de cis- et trans-verbenol Ctaient en correlation avec les taux de liberation de 3-carène, de myrcene et de $\beta$-pheilandrène. Ips latidens (LeConte) a manifesté une preference pour les pibges garnis d'ipsénol et de $\beta$-pheilandrène ou $\beta$-pinène, mais indépendamment de la dose. Les récoltes d'l. latidens dans les pièges garnis de la pheromone de cet insecte, l'ipsénol, se sont avérées inversement proportionnelles aux taux de liberation de 3-carène, de myrcene et de terpinolene. De même, les captures d'I pini dans les pièges garnis de sa pheromone, l'ipsdiénol, étaient inversement proportionnelles aux taux de liberation de myrcene et de terpinolène. Ces résultats démontrent l'existence d'une certaine spécificité chez chacune de ces trois espèces phloéophages quant aux odeurs d'hôtes qu'elles préfèrent. Les

\footnotetext{
l Author to whom all correspondence should be sent at the following address: Forestry Sciences Laboratory, Southern Research Station, USDA Forest Service, 320 Green Street, Athens, Georgia 30602.2044, United States (E-mail: dmiller/srs_athens@fs.fed.us).
} 
prédateurs/associés des scolytes Lasconotus complex LeConte (Coleoptera : Colydiidae) et Corticeus Piller et Mitterpacher sp. (Coleoptera : Tenebrionidae) ont démontré un certain degré de spécificité aux monoterpenes dans leurs reactions aux pièges à entonnoirs garnis d'ipsdiénol. L'y-terpinbne a augmenté l'attirance des pièges pour L. complex mais n'a pas eu d'effet sur Corticeus sp., alors que l' $\alpha$-pinène et la $\beta$-pinène ont augmenté l'attirance des pibges pour Corticeus sp., mais pas pour L. complex.

[Traduit par la Redaction]

\section{Introduction}

Bark beetles (Coleoptera: Scolytidae) continue to be primary pests of coniferous forests throughout British Columbia (Maclauchlan and Brooks 1994). Losses of spruce to spruce beetles, Dendroctonus rufipennis (Kirby), have amounted to $10 \%$ of all spruce volumes harvested in British Columbia (Humphreys and Safranyik 1993); losses of Douglas-fir to the Douglas-fir beetle, Dendroctonus pseudotsugae Hopkins, have exceeded 2.5 million cubic metres over the past 20 years (Humphreys 1995). The most dramatic impact on forested lands has been caused by the mountain pine beetle, Dendroctonus ponderosae Hopkins, which has killed over 500 million pines trees in British Columbia during the past 80 years (Unger 1993).

Mortality of trees is conditional upon the success of bark beetles in overcoming the various defenses that trees employ for protection against fungi, bacteria, bark beetles, and other insects (Berryman 1969; Shrimpton and Watson 1971; Shrimpton 1978; Cates and Alexander 1982; Payne 1983; Raffa and Berryman 1987). In addition to primary resinosus from severed resin ducts, trees attempt to flood wounded areas with traumatic resin (induced resinosus), defining the boundaries of such areas with necrotic tissue. Compounds such as monoterpenes, particularly in traumatic resin, may be toxic to bark beetles (Smith 1963; Reid and Gates 1970; Coyne and Lott 1976; Cates and Alexander 1982; Payne 1983; Raffa and Berryman 1983; Raffa et al. 1985).

Several species of bark beetles use monoterpenes as attractive kairomones (Wood 1982; Volz 1988; Borden 1989; Byers 1989). Monoterpenes may be released at higher rates than normal when phloem tissue is stressed (Madden 1977) or when physical damage occurs to the tissue (e.g., lightning strikes, wind damage, or mass attacks by bark beetles) (Wood 1982; Byers 1989). Furthermore, various species use monoterpenes as precursors for pheromones, having developed mechanisms to detoxify low concentrations of selected monoterpenes (Francke and Vité 1983; Pierce et al. 1987; Vanderwel and Oehlschlager 1987; Byers 1989; Gijzen et al. 1993).

In southern British Columbia, three species of bark beetles commonly attack lodgepole pine, Pinus contorta var. latifolia Engelmann (Pinaceae): Ips latidens (LeConte), Ips pini (Say), and Dendroctonus ponderosae. $\beta$-Phellandrene is attractive to both I. latidens and I. pini, alone or in combination with their pheromones (Miller and Borden 1990a, 1990b). Attraction of D. ponderosae to its pheromones is increased by myrcene (Billings et al. 1976; Borden et al. 1987) and 3-carene (Conn et al. 1983), and possibly by a-pinene, camphene, and terpinolene (Pitman 1971; Billings et al. 1976). Both $I$. pini and D. ponderosae have receptor cells on their antennae keyed to various monoterpenes. Myrcene and a-pinene activate cells in antennae of $I$. pini (Angst and Lanier 1979; Mustaparta et al. 1979). Antennae of D. ponderosae respond to a-pinene, B-pinene, camphene, 3-carene, myrcene, and limonene (Whitehead 1986).

Our objective was to determine the effects of seven major pine monoterpenes (Mirov 1961; Shrimpton 1972, 1973) on the attraction of I. latidens, I. pini, and D. ponderosae to their respective pheromones in stands of lodgepole pine. We tested two hypotheses: (1) all three species would show dose-dependent responses (responses 
that are directly or inversely proportional to release rates of monoterpenes); and (2) evidence of species specificity would be revealed by differing combinations of attractive or interruptive kairomones.

\section{Materials and Methods}

Twenty-one experiments were conducted in 1988 and 1989. The experiments attempted to determine the effects of 3 -carene, myrcene, $\beta$-phellandrene, a-pinene, $\beta$-pinene, y-terpinene, and terpinolene on the responses of (1) to its pheromone, ipsenol (Exps. 1-7); (2) I. pini to its pheromone, ipsdienol (Exps. 8-14); and (3) D. ponderosae to its pheromones exo-brevicomin and cis- and trans-verbenol (Exps. 15-21). Experiments 1-7 and 15-21 were conducted near Princeton $\left(49^{\circ} 27^{\prime} \mathrm{N}\right.$, $\left.120^{\circ} 31^{\prime} \mathrm{W}\right)$, British Columbia, where population levels of $I$. Iatidens and $\mathbf{D}$. ponderosae were high. In 1988, Experiments 8-14 were conducted near Williams Lake $\left(52^{\circ} 08^{\prime} \mathrm{N}\right.$, $\left.122^{\circ} 09^{\circ} \mathrm{W}\right)$, British Columbia, to exploit high population levels of I. pini. All experiments were set in mature stands of lodgepole pine.

In all experiments, replicates of six eight-unit, multiple-funnel traps (Lindgren 1983) (Phero Tech Inc., Delta, British Columbia) were set in grids of $2 \times 3$. Replicate grids were placed at least $100 \mathrm{~m}$ apart, and traps were spaced $10-15 \mathrm{~m}$ apart within each replicate. Each trap was suspended between trees by rope such that the top funnel of each trap was 1.3-1.5 m above ground. No trap was within $2 \mathrm{~m}$ of any tree.

Five replicate grids per experiment were set for Experiments 1-5 and 7 during the periods of 13 June - 19 July 1989, 3 I May - 21 June 1989, 23 June - 22 July 1988, 10 May 3 June 1989, 10 May 13 June 1989, and 9-28 June 1989, respectively. Six replicate grids were set for Experiment 6 from 28 June to 19 July 1989. Treatments, randomly assigned within each replicate, were as follows: (1) a control treatment of ipsenol alone; and (2-6) five treatments consisting of ipsenol and one monoterpene. The monoterpene treatments within a replicate differed only in release rates (Table 1). In Experiments 1-2 and 4-7, ipsenol was released from bubble-cap lures at 0.2-0.3 $\mathrm{mg} / \mathrm{d}$ at $24^{\circ} \mathrm{C}$ (Phero Tech Inc.). In Experiment 3, ipsenol was released at about $0.6 \mathrm{mg} / \mathrm{d}$ at $24^{\circ} \mathrm{C}$ from $10-\mathrm{cm}$ lengths of C-flex@ tubing (i.d. $1.6 \mathrm{~mm}$, o.d. $3.2 \mathrm{~mm}$ ) (Concept Inc., Clearwater, Florida), filled with an ethanol solution of ipsenol, and heat-pressure sealed at both ends (Phero Tech Inc.).

In 1988, five replicate grids per experiment were set for Experiments 8-14 during the periods of 29 August 7 September, 17-27 August, 9-18 August, 31 August 7 September, 28 August - 7 September, 27-29 August, and 7-18 September, respectively. Treatments were as in Experiments 1-7 (monoterpene release rates listed in Table 1) and ipsdienol replaced ipsenol. As with ipsenol in Experiment 3, ipsdienol was released from C-flex ${ }^{\circledR}$ lures at about $0.6 \mathrm{mg} / \mathrm{d}$ (Phero Tech Inc.).

Five replicate grids per experiment were set for Experiments 15-21 during the periods of 25 July - 10 August 1989, 14-24 August 1988, 4-14 August 1988, 19 July 10 August 1989, 19 July - 1 August 1989, 6 August - 2 September 1989, and 24 August - 1 September 1988, respectively. Treatments were as in Experiments 1-14 (monoterpene release rates listed in Table 1) and ipsenol and ipsdienol replaced with exo-brevicomin, and cis- and trans-verbenol. The mix of cis- and trans-verbenol was released from bubble-cap lures at a combined rate of about $1.74 \mathrm{mg} / \mathrm{d}$ at $24^{\circ} \mathrm{C}$ (determined by weight loss). In Experiments 16, 17, and 21, exo-brevicomin was released from glass capillary tube lures at about $0.15 \mathrm{mg} / \mathrm{d}$ at $20^{\circ} \mathrm{C}$ (determined by weight loss). In Experiments 15 and 18-20, exo-brevicomin was released from laminar lures at about $0.1 \mathrm{mg} / \mathrm{d}$ at $24^{\circ} \mathrm{C}$ (Phero Tech Inc.). 
TABLE 1. Release rates of monoterpenes ( $\mathrm{mg} / \mathrm{d}$ at $27-30^{\circ} \mathrm{C}$ ) targeted for Zps latidens, Zps pini, and Dendroctonus ponderosae.

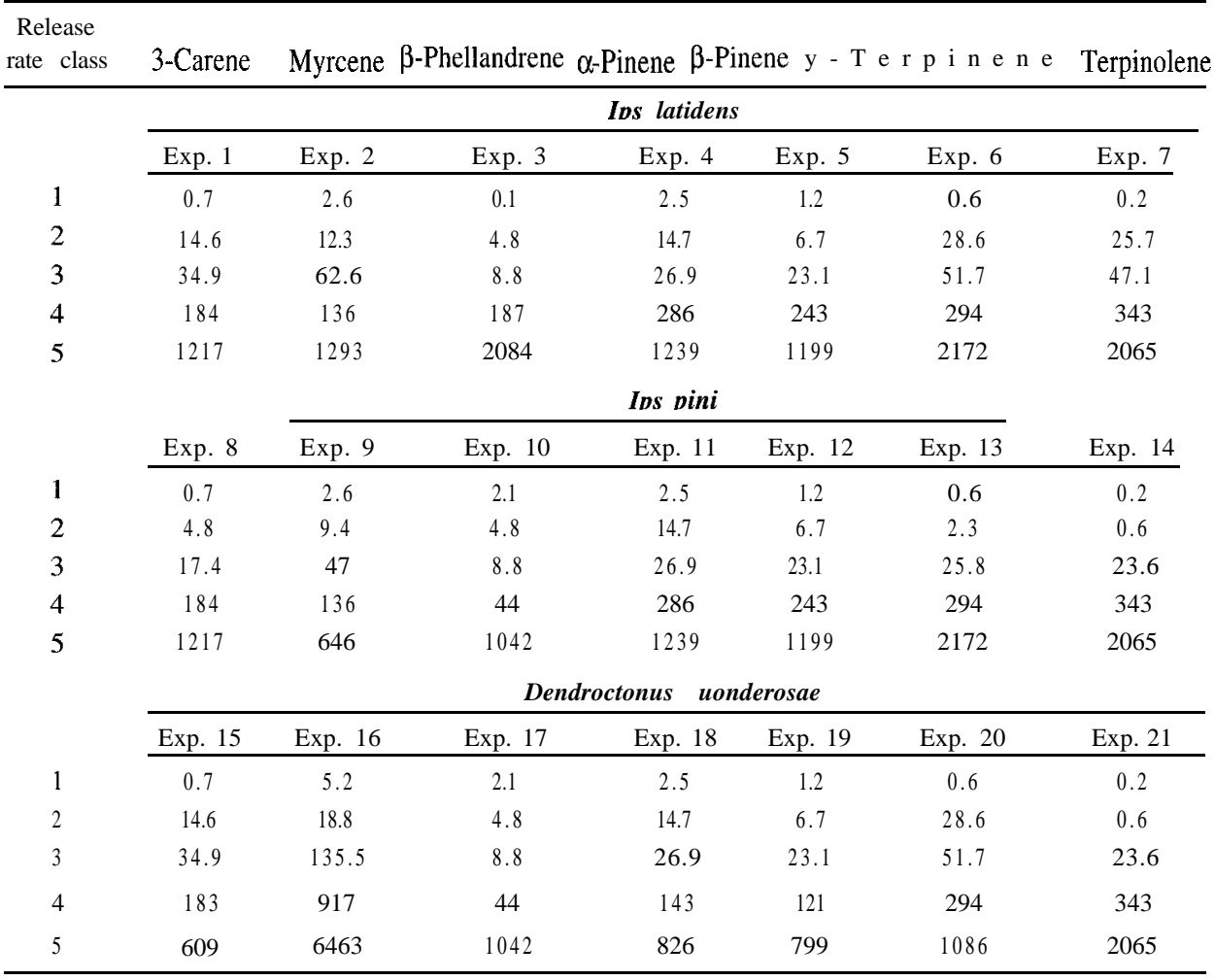

In 1988, (+)-3-carene, (-)- $\beta$-phellandrene, $(-)$ - $\alpha$-pinene, $(-)-\beta$-pinene, y-terpinene, and terpinolene (all chemical purities $>95 \%$ ) were obtained from HD Pierce, Jr (Department of Chemistry, Simon Fraser University). In 1989, (+)-3-carene, (-)-a-pinene, $(-)-\beta$-pinene, and y-terpinene (all chemical purities $>95 \%$ ) were obtained from Aldrich Chemical Co. (Milwaukee, Wisconsin) and terpinolene (chemical purity 94\%) was obtained from D Vanderwel (Department of Chemistry, Simon Fraser University). Phero Tech Inc. supplied the following: (1) $\beta$-myrcene (chemical purity 98\%); (2) (+)-ipsenol (chemical purity 98\%); (3) (+)-ipsdienol (chemical purity 98\%); (4) polyethylene bubble-cap lures containing (+)-ipsenol (chemical purity 98\%) in 3-butanediol; (5) polyethylene bubble-cap lures containing a 13:87 mixture of cis- and trans-verbenol [both chemical purities 98\%; both enantiomeric compositions 83:17 (-):(+)I; (6) laminar exo-brevicomin lures (chemical purity 98\%); and (7) open polyethylene microcentrifuge tubes (400 mL) (Evergreen Scientific, Los Angeles, California), each containing a 3-cm-long glass capillary tube (i.d. $13 \mathrm{~mm}$, o.d. $15 \mathrm{~mm}$ ) filled with exo-brevicomin (chemical purity $98 \%$ ).

The following devices were used to release monoterpenes: (1) open polypropylene microcentrifuge tubes (1.5 mL) (Quality Scientific Plastics, Petaluma, California), each containing one 2-cm-long glass capillary tube (i.d. $1.5 \mathrm{~mm}$, o.d. $1.8 \mathrm{~mm}$ ), sealed at one end and filled with a monoterpene; (2) open polypropylene microcentrifuge tubes $(1.5 \mathrm{~mL})$ (Quality Scientific Plastics), each containing live 2-cm-long glass capillary tubes (i.d. $1.5 \mathrm{~mm}$, o.d. $1.8 \mathrm{~mm}$ ), sealed at one end and filled with a monoterpene; (3) closed polyethylene microcentrifuge tubes $(0.25 \mathrm{~mL})$ (Evergreen Scientific) filled 
with a monoterpene; (4) closed polyethylene microcentrifuge tubes $(0.4 \mathrm{~mL})$ (Evergreen Scientific) filled with a monoterpene; (5) closed polyethylene microcentrifuge tubes $(1.8 \mathrm{~mL})$ (Evergreen Scientific) filled with a monoterpene; (6) polyethylene transfer pipettes (3.5 mL) (Saint-Amand Mfg. Co., San Fernando, California) filled with a monoterpene and heat-pressure sealed; and (7) closed polyethylene screw-cap bottles $(1.5 \mathrm{~mL})$ (Ampak Inc., Richmond, British Columbia) filled with a monoterpene. The ranges of release rates (Table 1) were obtained through different numbers and combinations of lures to achieve an even distribution along a logarithmic scale. Some lure combinations were changed in 1989 because the rates determined concurrently with the experiments did not achieve this distribution.

For determinations of sex ratio in trap catches, subsamples $(n=30-50)$ of captured beetles from each experiment were taken at random from catches in traps baited with monoterpene rate classes 1,3 , and 5 (Table 1). Sexes of $I$. pini were determined using declivital characters (Lanier and Cameron 1969), whereas those of $I$. Iatidens and D. ponderosae were determined by dissection and examination of genitalia. Voucher specimens were deposited at the Entomology Museum, Simon Fraser University.

Trap catch data were analyzed using the SAS statistical package version 5.0 (SAS Institute Inc., Cary, North Carolina). One replicate in Experiment 19 was excluded from analyses because only 12 beetles were captured. Data were transformed by $\ln (Y)$ to remove heteroscedasticity and regressed against the release rate of monoterpene, transformed by $\ln (X)$, using a general linear model. Residuals were examined to ensure the appropriateness of a linear model and the range of the regression lines. The transformed data for each experiment were subjected to two-way analysis of variance (ANOVA) using replicate and treatment as model factors. In each experiment, five orthogonal comparisons were performed using protocols in Sokal and Rohlf (1981, pp. 233-242). Sex ratio data were analyzed by $\chi^{2}$ tests of independence using the Minitab statistical package (Department of Statistics, Pennsylvania State University, University Park, Pennsylvania). Trap catch data for non-scolytid beetle species were analyzed by Fisher's least significant difference (LSD) test using the SYSTAT statistical package version 7.0 (SPSS Inc., Chicago, Illinois).

\section{Results}

All three species showed dose-dependent responses to 3-carene and myrcene (Figs. 1-3). Catches of $I$. latidens were inversely proportional to the release rate of 3-carene (Fig. 1A), whereas those of I. pini and D. ponderosae were directly proportional (Figs. 2A, 3A). Catches of $I$. Iatidens in traps baited with 3-carene at the highest release rates were lower than those in the control traps $\left(F_{1,18}=13.31, \mathbf{P}=0.002\right)$. Relative to control traps, traps baited with 3-carene at the two highest release rates caught more I. pini $\left(F_{1,24}=38.22, \mathbf{P}<0.001\right.$; and $F_{1,24}=49.01, \mathbf{P}<0.001$, respectively $)$. Traps baited with 3 -carene at the highest rate caught more $\mathbf{D}$. ponderosae than control traps $\left(F_{1,24}=\mathbf{4 . 8 0}, \mathbf{P}=\mathbf{0 . 0 4 0}\right)$.

Trap catches of both $I$. Iatidens and $I$, pini were inversely proportional to the release rate of myrcene (Figs. $1 \mathrm{~B}, 2 \mathrm{~B}$ ), whereas those of $\mathbf{D}$. ponderosae were directly proportional (Fig. 3B). Relative to controls, traps baited with myrcene at the three highest release rates caught fewer $I$. Iatidens $\left(F_{1,18}=\mathbf{5 . 4 0}, \mathbf{P}=\mathbf{0 . 0 3 5} ; F_{1,18}=\mathbf{8 . 7 2}, \mathbf{P}=0.010\right.$; and $\mathbf{F}_{,, 18}=7.24, \mathbf{P}=0.017$, respectively $)$ and $I$. pini $\left(F_{1,23}=12.35, \mathbf{P}=\mathbf{0 . 0 0 2 ;} F_{1,23}=\right.$ $10.23, P=0.005$; and $F_{1,23}=15.59, P<0.001$, respectively). Catches of $\mathbf{D}$. ponderosae were higher in traps baited with myrcene at the two highest release rates than those in control traps $\left(F_{1,23}=\mathbf{4 . 1 1}, \mathbf{P}=0.042\right.$; and $F_{1,23}=12.42, \mathbf{P}=0.002$, respectively $)$. 


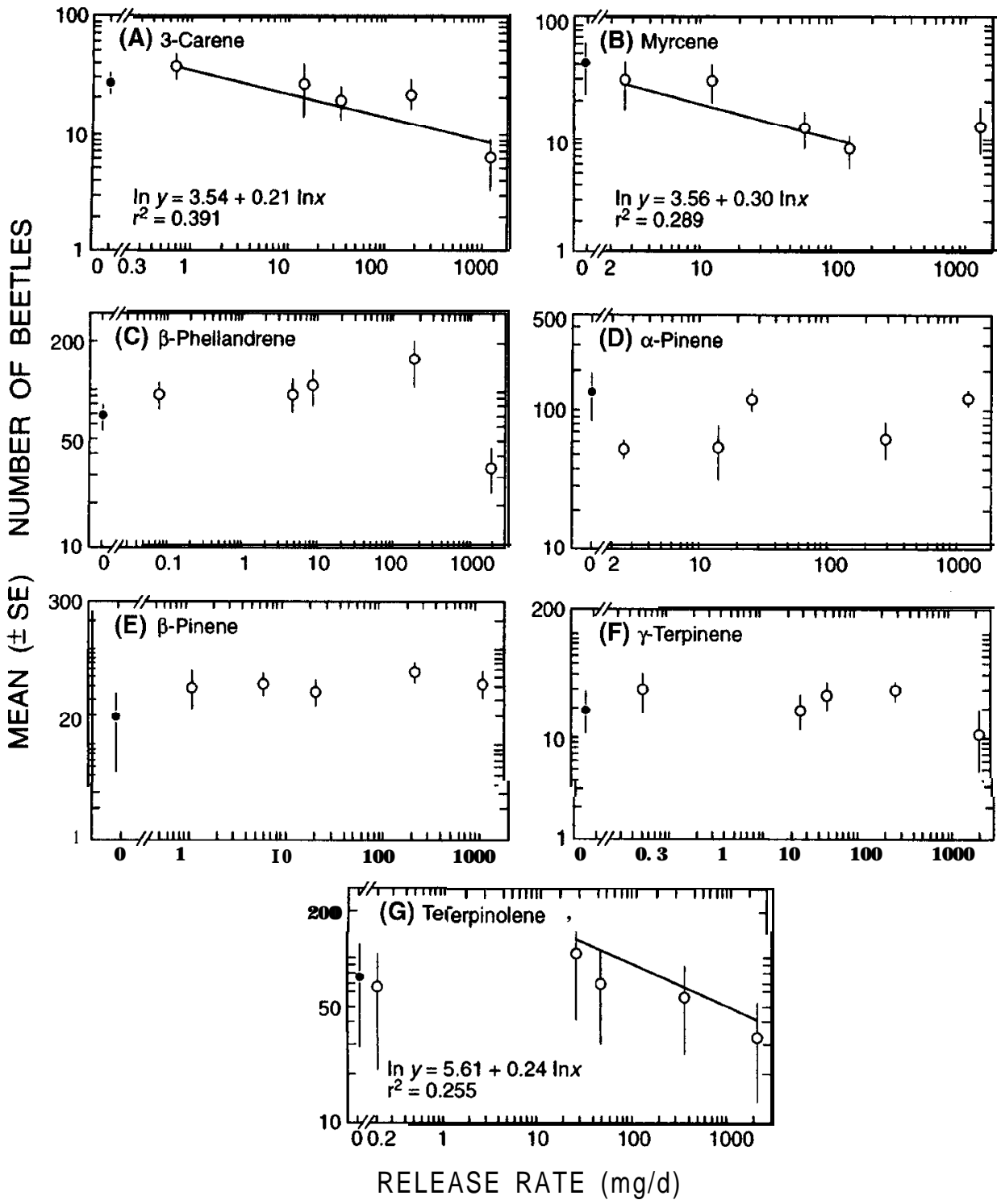

FIGURE 1. Effects of 3-carene (A), myrcene (B), $\beta$-phellandrene (C), a-pinene (D), $\beta$-pinene (E), $\gamma$-terpinene $(F)$, and terpinolene $(G)$ on the attraction of $3 p s$ latidens to multiple-funnel traps baited with ipse nol. Slopes of regression lines are significantly different from zero $(t$ test, $P=0.003,0.032$, and 0.054 , respectively). Solid circles represent data for traps without monoterpene devices.

All three species showed attraction to $\beta$-phellandrene. Catches of I. latidens in traps baited with ipsenol and $\beta$-phellandrene released at the second highest rate were greater than those in control traps $\left(F_{1,24}=5.70, P=0.027\right)$, even though there was no evidence of a dose-dependent response (Fig. 1C). However, catches of I.latidens in traps with $\beta$-phellandrene at the highest release rate were lower than those in control traps $\left(F_{1,24}=10.97, P=0.004\right)$. Ips pini and D. ponderosae exhibited dose-dependent attraction to $\beta$-phellandrene (Figs. 2C, 3C). Catches of both species were directly proportional to the release rate of $\beta$-phellandrene. Catches of $I$. pini in traps baited with 

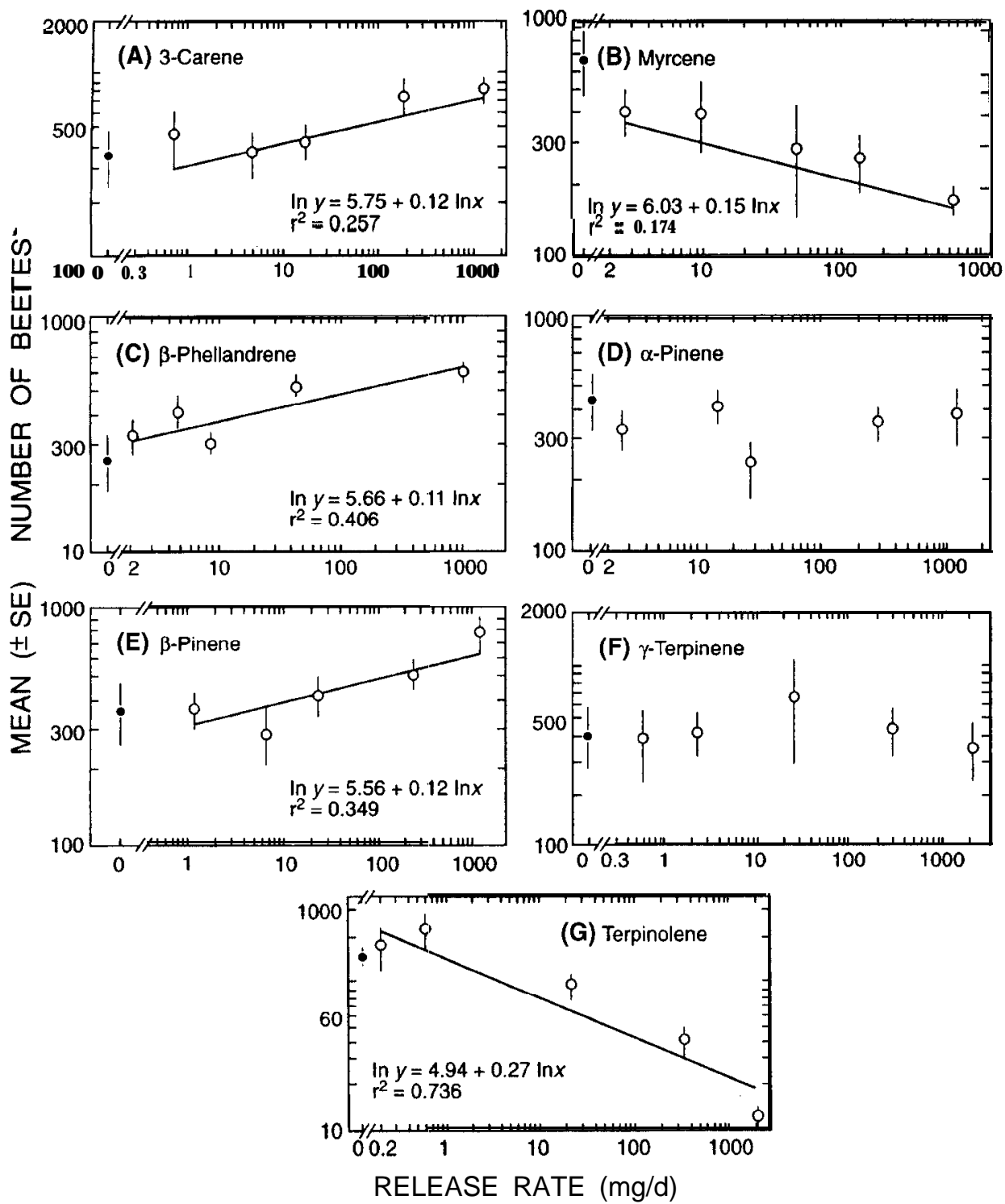

Figure 2. Effects of 3-carene (A), myrcene (B), $\beta$-phellandrene (C), a-pinene (D), $\beta$-pinene (E), $\gamma$-terpinene $(F)$, and terpinolene $(G)$ on the attraction of Ips pini to multiple-funnel traps baited with ipsdienol. Slopes of regression lines are significantly different from zero $(t$ test, $P=0.01,0.038,<0.001$, 0.002 , and $<0.001$, respectively). Solid circles represent data for traps without monoterpene devices.

treatments 2, 4, and 5 were greater than those in the control traps $(\mathrm{F}, 24=11.47, P=$ $0.003 ; F_{1,24}=25.57, P<0.001$; and $F_{1,24}=34.49, P<0.001$, respectively).

There was no discernible effect of a-pinene on catches of I. latidens, I. pini, and D. ponderosae (Figs. 1D, 2D, and 3D). In contrast, $\beta$-pinene affected the pheromone responses of two of the three species. Ips pini exhibited dose-dependent attraction to $\beta$-pinene (Fig. 2E). Catches in traps baited with $\beta$-pinene at the two highest release rates were greater than those in the control traps $\left(F_{1.24}=5.94, P=0.024\right.$; and $F_{1,23}=21.57$, $P<0.001$, respectively). Catches of I. latidens in traps baited with $\beta$-pinene were not 

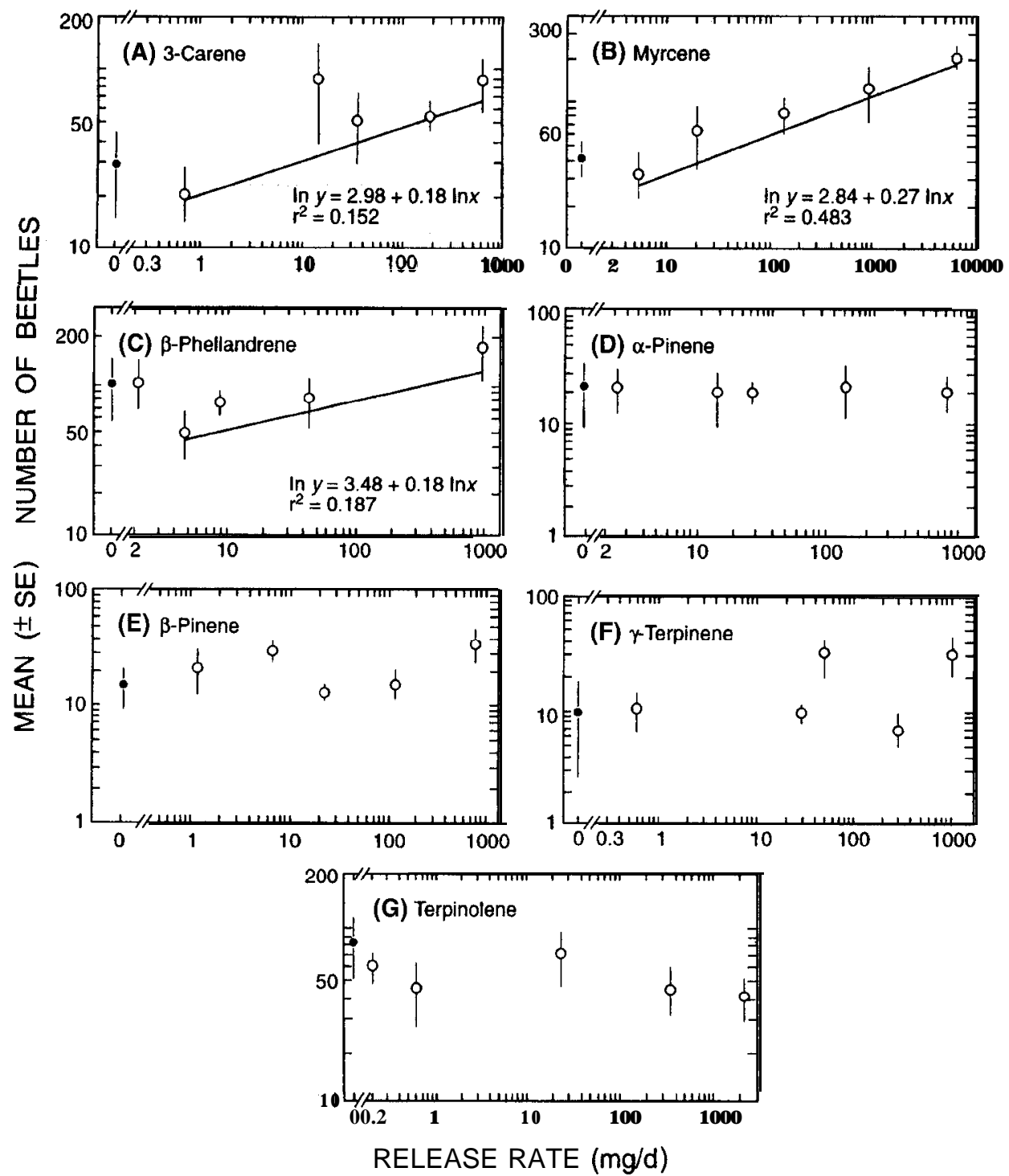

Figure 3. Effects of 3-carene (A), myrcene (B), $\beta$-phellandrene (C), $\alpha$-pinene (D), $\beta$-pinene (E), $\gamma$-terpinene $(F)$, and terpinolene $(G)$ on the attraction of Dendroctonus ponderosae to multiple-funnel traps baited with exo-brevicomin and trans- and cis-verbenol. Slopes of regression lines are significantly different from zero ( $t$ test, $P=0.054,<0.001$, and 0.057 , respectively). Solid circles represent data for traps without monoterpene devices.

affected in a dose-dependent fashion, although catches in traps with the two highest rates were greater than those in the control traps $\left(F_{1,23}=7.57, P=0.013\right.$; and $F_{1,23}=$ 4.88, $P=0.040$, respectively) (Fig. 1E).

None of the species showed dose-dependent responses to y-terpinene (Figs. 1F, $2 \mathrm{~F}$, and $3 \mathrm{~F}$ ). Catches of $D$. ponderosae in traps baited with y-terpinene at two of the three highest release rates were greater than those in the control traps $\left(F_{1,12}=6.22, P=\right.$ 0.032 ; and $F_{1,12}=6.56, P=0.028$, respectively). 
TABle 2. Mean ( \pm SE) number of Corticeus sp. (Coleoptera: Tenebrionidae) captured in multiple-funnel traps $(n=5)$ baited with ipsdienol and various monoterpenes.

\begin{tabular}{cccccc}
\hline \multirow{2}{*}{$\begin{array}{c}\text { Release } \\
\text { rate class* }\end{array}$} & $\alpha$-Pinene & $\beta$-Pinene & 3-Carene & y-Terpinene & $\beta$-Phellandrene \\
\cline { 2 - 6 } Control & $17.2 \pm 2.7 a b$ & $26.6 \pm 9.7 a b$ & $19.0 \pm 1.7 b$ & $14.0 \pm 6.0 a$ & $2.4 \pm 1.1 a$ \\
$\mid$ & $16.0 \pm 1.6 a$ & $26.0 \pm 10.3 a$ & $10.8 \pm 2.5 a$ & $19.4 \pm 7.9 a$ & $3.6 \pm 0.9 a$ \\
2 & $23.5 \pm 4.0 a b$ & $27.4 \pm 4.1 a b$ & $16.6 \pm 1.8 b$ & $12.4 \pm 5.4 a$ & $1.6 \pm 0.6 a$ \\
3 & $29.0 \pm 4.0 b$ & $44.2 \pm 10.2 b$ & $41.6 \pm 5.4 c$ & $12.0 \pm 1.9 a$ & $2.4 \pm 1.0 a$ \\
4 & $61.6 \pm 10.6 c$ & $114.0 \pm 26.0 c$ & $76.6 \pm 7.1 d$ & $9.8 \pm 1.8 a$ & $4.6 \pm 1.9 a$ \\
5 & $105.0 \pm 25.7 c$ & $200.0 \pm 56.9 c$ & $102.2 \pm 11.5 d$ & $9.4 \pm 2.0 a$ & $13.0 \pm 3.3 b$ \\
\hline
\end{tabular}

NoтE: Means within a column followed by a different letter are significantly different (Fisher's least significant difference test, $P=0.05$ ).

* Monoterpene release rates as listed in Table I.

Terpinolene significantly reduced trap catches of all three species. Catches of I. latidens and I. pini were inversely proportional to the release rate of terpinolene (Figs. 1G, 2G). Catches of I. pini in traps baited with terpinolene at the two highest release rates were lower than those in the control traps $\left(F_{1.24}=25.06, P<0.001\right.$; and $F_{1.24}$ $=69.30, P<0.001$, respectively). Catches of $D$. ponderosae were lower in traps baited with terpinolene at the highest release rate than in the control traps $\left(F_{1,24}=4.50, P=\right.$ 0.047).

Evidence of sex-specific responses of the three species to different release rates of monoterpenes was found in only two experiments. The proportion of male I. pini caught in traps baited with $\beta$-phellandrene increased as the release rate of $\beta$-phellandrene increased $\left(\chi^{2}=5.46, P<0.025\right)$. The proportion of male $D$. ponderosae in traps baited with y-terpinene decreased as the release rate of y-terpinene increased $\chi^{2}=7.99, P<$ 0.01). The mean \pm SE proportion of male I. latidens and $I$. pini, in experiments lacking any association between sex ratio and release rates of monoterpenes, was $0.20 \pm 0.02$ in both cases. The mean \pm SE proportion of male $D$. ponderosae caught in experiments lacking any association between sex ratio and release rate of monoterpenes was $0.51 \pm$ 0.04 .

Two beetle species associated with bark beetles were captured in large numbers. Catches of Corticeus Piller and Mitterpacker sp. (Coleoptera: Tenebrionidae) to traps baited with ipsdienol were affected by a-pinene, $\beta$-pinene, 3 -carene, and $\beta$-phellandrene (Table 2). The highest catches were found in traps with the highest release rates of monoterpenes. y-Terpinene had no effect on trap catches. Similarly, catches of Lasconotus complex LeConte (Coleoptera: Colydiidae) in ipsdienol-baited traps were highest in those baited with 3-carene and $\beta$-phellandrene, released at the highest rates (Table 3). a-Pinene and $\beta$-pinene had no effect on catches, and catches to traps baited with y-terpinene seemed highest in the intermediate range of release rates.

\section{Discussion}

Species specificity in host location by I. latidens, I. pini, and D. ponderosae can be achieved by the use of the pheromones ipsenol, ipsdienol, and exo-brevicomin with cis- and trans-verbenol. Our results indicate that responses to monoterpenes can enhance separation among these three species (Table 4).

Attraction of all three species is enhanced by $\beta$-phellandrene, the principal constituent of gum turpentine from lodgepole pine (Mirov 1961). Increasing release rates of 3 -carene and myrcene reduces the attraction of I. latidens but increases the attraction of $D$. ponderosae. Attraction of $I$. pini is increased by 3-carene but reduced by myrcene. 
TABLE 3. Mean ( $\pm \mathrm{SE}$ ) number of Lasconotus complex (Coleoptera: Colydiidae) captured in multiple-funnel $(n=5)$ traps baited with ipsdienol and various monoterpenes.

\begin{tabular}{cccccc}
\hline \multirow{2}{*}{$\begin{array}{c}\text { Release } \\
\text { rate class* }\end{array}$} & a-Pinene & $\beta$-Pinene & 3-Carene & y-Terpinene & $\beta$-Phellandrene \\
\cline { 2 - 6 } Control & $90 \pm 40.5 a$ & $50 \pm 12.8 a$ & $101 \pm 53.6 a$ & $46 \pm 18.6 a$ & $10 \pm 2.5 a$ \\
$\mid$ & $68 \pm 27.4 a$ & $50 \pm 17.9 a$ & $40 \pm 9.4 a$ & $79 \pm 24.9 a$ & $36 \pm 6.7 b$ \\
2 & $77 \pm 25.5 a$ & $41 \pm 6.3 a$ & $98 \pm 30.6 a$ & $127 \pm 28.2 a b$ & $39 \pm 7.4 b$ \\
3 & $92 \pm 28.8 a$ & $68 \pm 12.8 a$ & $304 \pm 72.1 b$ & $157 \pm 36.3 b$ & $67 \pm 16.9 b$ \\
4 & $110 \pm 39.1 a$ & $52 \pm 12.7 a$ & $666 \pm 223.4 b$ & $126 \pm 16.8 b$ & $112 \pm 20.0 c$ \\
5 & $105 \pm 38.6 a$ & $64 \pm 14.1 a$ & $572.2 \pm 170.1 b$ & $109 \pm 31.4 b$ & $181 \pm 25.1 c$ \\
\hline
\end{tabular}

NOTE: Means within a column followed by a different letter are significantly different (Fisher's least significant difference test, $P=0.05$ ).

* Monoterpene release rates as listed in Table 1.

TABLE 4. Summary of positive $(+)$, neutral $(0)$, and negative $(-)$ effects of monoterpenes on the responses of three sympatric pine bark beetles to pheromone-baited funnel traps.

\begin{tabular}{lcccc}
\hline Monoterpene & Ips latidens & & Ips pini & $\begin{array}{c}\text { Dendroctonus } \\
\text { ponderosae }\end{array}$ \\
\cline { 4 - 5 } 3-Carene & - & & + & + \\
Myrcene & & & - & + \\
$\beta$-Phellandrene & + & & + & + \\
a-Pinene & 0 & & & 0 \\
$\beta-P i n e n e$ & + & & + & $+/ O$ \\
y-Terpinene & 0 & $\mathbf{0}$ & $+/ O$ \\
Terpinolene & & - & -10 \\
\hline
\end{tabular}

The attraction of $D$. ponderosae to 3-carene and myrcene (Figs. 3A, 3B) is consistent with Billings et al. (1976), Conn et al. (1983), and Borden et al. (1987). Conn et al. found that $\beta$-phellandrene had no effect on $D$. ponderosue; however, they employed low release rates $(7 \mathrm{mg} / \mathrm{d})$, comparable to our lowest release rate, which showed little effect. The attraction of I. lutidens and I. pini to monoterpenes is consistent with Miller and Borden $(1990 a, 1990 b)$.

Some evidence of multifunctionality in the responses of beetles to monoterpenes was apparent. $\beta$-Phellandrene at the highest release rate inhibited the response of I. lutidens to ipsenol-baited traps, whereas at the second-highest release rate it resulted in trap catches greater than those in the controls. In contrast, trap catches of $D$. ponderosae were reduced with the second-lowest release rate of $\beta$-phellandrene but then increased in direct proportion to the release rate of $\beta$-phellandrene. Dendroctonus ponderosue may prefer hosts releasing large amounts of $\beta$-phellandrene, whereas I. lutidens may prefer hosts releasing only low amounts. This hypothesis is consistent with the observation that I. lutidens seems to prefer drier phloem tissue than that preferred by D. ponderosue (Miller and Borden 1985), which attacks mature lodgepole pines (Safranyik et al. 1974) that produce copious amounts of resin (Shrimpton 1978; Cates and Alexander 1982; Raffa and Berryman 1987), presumably with a high $\beta$-phellandrene content. Species specificity in the use of kairomones suggests that beetles may respond best to stimuli that convey information regarding the presence of preferred host qualities, indicating hosts in which they would have a competitive advantage. 
Dose-dependent functions were noted in 11 of the 21 experiments conducted on these three species (Figs. 1-3). This type of behavioral response may reflect variation in host availability and quality, even in the absence of pheromones. Each species may be able to breed in lodgepole pine phloem with various compositions of monoterpenes, although there may be an optimal blend. Alternatively, variation in responses may reflect abilities of beetles to invade phloem of other pine species. 3-Carene and $\beta$-pinene are the major constituents of gum turpentine from ponderosa pine, Pinus ponderosa $\mathrm{P}$. Laws. ex C. Laws. (Mirov 1961). Resin of western white pine, Pinus monticola Dougl. ex D. Don, contains primarily $\alpha$ - and $\beta$-pinene (Mirov 1961). 3-Carene is also a major constituent of gum turpentine from whitebark pine, Pinus albicaulis Engelmann (Mirov 1961). All four hosts are found in southern British Columbia. Habitats used by bark beetles tend to be patchy and ephemeral (Atkins 1968; Alcock 1982). Beetles may not have the luxury of waiting for an optimal host patch. Even when a host is found, the optimal areas for breeding may already be taken by conspecifics, thereby iorcing the newcomer into suboptimal phloem conditions.

Predators may also exhibit specificity in responses to host compounds, possibly relating to the abundance of preferred prey items associated with various combinations of monoterpenes. Lasconotus and Corticeus species have been implicated as predators of bark beetle eggs and larvae (Parker and Davis 1971; Hackwell 1973; Furniss and Carolin 1980; Triplehorn 1990), possibly gaining benefits by responding to both host odors and beetle-produced pheromones. Attraction of both L. complex and Corticeus sp. was increased by $\beta$-phellandrene and 3-carene. Attraction of L. complex was also increased by y-terpinene, which had no effect on Corticeus sp. In contrast, attraction of Corticeus sp. was increased by both $\alpha$ - and $\beta$-pinene which had no effect on $L$. complex.

\section{Acknowledgments}

We thank L Wheeler, T Richerson, C Matteau, and LJ Chong for technical support. Assistance in the manufacture of devices was kindly provided by Phero Tech Inc. This research was supported in part by an HR MacMillan Family Fund Fellowship and a Simon Fraser University Graduate Research Fellowship to DRM, the Natural Sciences and Engineering Research Council of Canada, and the Science Council of British Columbia.

\section{References}

Alcock J. 1982. Natural selection and communication among bark beetles. Florida Entomologist 65: 17-32 Angst ME, Lanier GN. 1979. Electroantennogram responses of two populations of Ips pini (Coleoptera: Scolytidae) to insect-produced and host tree compounds. Journal of Chemical Ecology 5: 131-40

Atkins MD. 1968. Scolytid pheromones - ready or not. The Canadian Entomologist 100: 1115-17

Berryman AA. 1969. Responses of Abies grandis to attack by Scolytus ventralis (Coleoptera: Scolytidae). The Canadian Entomologist 101: 1033-41

Billings RF, Gara RI, Hrutfiord BE 1976. Influence of ponderosa pine resin volatiles on the response of Dendroctonus ponderosae to synthetic trans-verbenol. Environmental Entomology 5: 17 1-9

Borden JH. 1989. Semiochemicals and bark beetle populations: exploitation of natural phenomena by pest management strategists. Holarctic Ecology 12: 501-10

Borden JH, Ryker LC, Chong LJ, Pierce HD, Jr, Johnston BD, Oehlschlager AC. 1987. Response of the mountain pine beetle, Dendroctonus ponderosae Hopkins (Coleoptera: Scolytidae), to five semiochemicals in British Columbia lodgepole pine forests. Canadian Journal of Forest Research 17: $118-28$

Byers JA. 1989. Chemical ecology of bark beetles. Experentia 45: 271-83

Cates RG, Alexander H. 1982. Host resistance and susceptibility. pp. 212-63 in JB Mitton, KB Sturgeon (Eds.), Bark beetles in North American conifers. Austin: University of Texas Press 
Conn JE, Borden JH, Scott BE, Friskie LM, Pierce HD, Jr, Oehlschlager AC. 1983. Semiochemicals for the mountain pine beetle, Dendroctonus ponderosae (Coleoptera: Scolytidae) in British Columbia: field trapping studies. Canadian Journal of Forest Research 13: $320-4$

Coyne JF, Lott LH. 1976. Toxicity of substances in pine oleoresin to southern pine beetle. Journal of the Georgia Entomological Society 11: 301-5

Francke W, Vité JP. 1983. Oxygenated terpenes in pheromone systems of bark beetles. Zeitschrift Angewandte Entomologie 96: 146-56

Furniss RL, Carolin VM. 1980. Western forest insects. United States Department of Agriculture Forest Service Miscellaneous Publication 1339

Gijzen M, Lewinson E, Savage TJ, Croteau RB. 1993. Conifer monoterpenes. Biochemistry and bark beetle chemical ecology. pp 8-22 in R Teranishi, RG Buttery, H Sugisawa (Eds.), Bioactive volatile compounds from plants. Washington: American Chemical Society

Hackwell GA. 1973. Biology of Lasconotus subcostulatus (Coleoptera: Colydiidae) with special reference to feeding behavior. Annals of the Entomological Society of America 66: 62-5

Humphreys N. 1995. Douglas-fir beetle in British Columbia. Forestry Canada Forest Pest Leaflet 14

Humphreys N, Safranyik L. 1993. Spruce beetle. Forestry Canada Forest Pest Leaflet 13

Lanier GN, Cameron EA. 1969. Secondary sexual characters in the North American species of the genus Ips (Coleoptera: Scolytidae). The Canadian Entomologist 101: 862-70

Lindgren BS. 1983. A multiple-funnel trap for scolytid beetles. The Canadian Entomologist 115: 299-302

Maclauchlan LE, Brooks JE. 1994. Strategies and tactics for managing the mountain pine beetle, Dendroctonus ponderosae. Kamloops: British Columbia Ministry of Forests

Madden JL. 1977. Physiological reactions of Pinus radiata to attack by woodwasp, Sirex noctilio F. (Hymenoptera: Siricidae). Bulletin of Entomological Research 67: 405-26

Miller DR, Borden JH. 1985. Life history and biology of Ips latidens (LeConte) (Coleoptera: Scolytidae). The Canadian Entomologist 117: 859-71

1990a. The use of monoterpenes as kairomones by Ips latidens (LeConte) (Coleoptera: Scolytidae). The Canadian Entomologist 122: 301-7

1990b. $\beta$-Phellandrene: kairomone for pine engraver, Ips pini (Say) (Coleoptera: Scolytidae). Journal of Chemical Ecology 16: 2519-31

Mirov NT. 1961. Composition of gum turpentines of pines. United States Department of Agriculture Forest Service Technical Bulletin 1239

Mustaparta H, Angst ME, Lanier GN. 1979. Specialization of olfactory cells to insect- and host-produced volatiles in the bark beetle Zps pini (Say). Journal of Chemical Ecology 5: 109923

Parker DL, Davis DW. 1971. Feeding habits of Corticeus substriatus (Coleoptera: Tenebrionidae) associated with the mountain pine beetle in lodgepole pine. Annals of the Entomological Society of America 64: 2934

Payne TL. 1983. Nature of insect and host tree interactions. Journal of Applied Entomology 96: 105-9

Pierce HD, Jr, Conn JE, Oehlschlager AC, Borden JH. 1987. Monoterpene metabolism in female mountain pine beetles, Dendroctonus ponderosae Hopkins, attacking ponderosa pine. Journal of Chemical Ecology 13: $1455-80$

Pitman GB. 1971. Trans-Verbenol and alpha-pinene: their utility in manipulation of the mountain pine beetle. Journal of Economic Entomology 64: 426-30

Raffa KF, Berryman AA. 1983. The role of host plant resistance in the colonization behavior and ecology of bark beetles (Coleoptera: Scolytidae). Ecological Monographs 53: 27-49

- 1987. Interacting selective pressures in conifer - bark beetle systems: a basis for reciprocal adaptations? American Naturalist 129: 234-62

Raffa KF, Berryman AA, Simasko J, Teal W, Wong BL. 1985. Effects of grand fir monoterpenes on the fir engraver, Scolytus ventralis (Coleoptera: Scolytidae), and its symbiotic fungus. Environmental Entomologist 14: 552-6

Reid RW, Gates H. 1970. Effect of temperature and resin on hatch eggs of the mountain pine beetle (Dendroctonus ponderosae). The Canadian Entomologist 102: 617-22

Safranyik L, Shrimpton DM, Whitney HS. 1974. Management of lodgepole pine to reduce losses from the mountain pine beetle. Forestry Canada Forestry Technical Report 1

Shrimpton DM. 1972. Variation in the extractives from lodgepole pine sapwood and heartwood. Forestry Canada Information Report NOR-X-18

- 1973. Extractives associated with wound response of lodgepole pine attacked by the mountain pine beetle and associated microorganisms. Canadian Journal of Botany 51: 527-34

1978. Resistance of lodgepole pine to mountain pine beetle infestations. pp 64-76 in AA Berryman, GD Amman, RW Stark (Eds.), Theory and practice of mountain pine beetle management in lodgepole pine forests. Moscow: Idaho University Press

Shrimpton DM, Watson JA. 1971. Response of lodgepole seedlings to inoculation with Europhium clavigerum, a blue stain fungus. Canadian Journal of Botany 49: $373-5$ 
Smith RH. 1963. Toxicity of pine resin vapors to three species of Dendroctonus bark beetles. Journal of Economic Entomology 56: 827-3 1

Sokal RR, Rohlf FJ. 1981. Biometry. San Francisco: W.H. Freeman and Company

Triplehorn CA. 1990. Review of the genus Corticeus (Coleoptera: Tenebrionidae). Annals of the Entomological Society of America 83: 287-306

Unger L. 1993. Mountain pine beetle. Forestry Canada Forest Pest Leaflet 76

Vanderwel D, Oehlschlager AC. 1987. Biosynthesis of pheromones and endocrine regulation of pheromone production in Coleoptera. pp 175-215 in GJ Blomquist, GD Prestwich (Eds.), Pheromone biochemistry. New York: Academic Press

Volz H-A. 1988. Monoterpenes governing host selection in the bark beetles Hylurgops palliatus and Tomicus piniperda. Entomologia Experimentalis et Applicata 47: 31-5

Whitehead AT. 1986. Electroantennogram responses by mountain pine beetles, Dendroctonus ponderosae Hopkins, exposed to selected semiochemicals. Journal of Chemical Ecology 12: 1603-21

Wood DL. 1982. The role of pheromones, karromones, and allomones in the host selection and colonization behavior of bark beetles. Annual Review of Entomology 27: 41 1-46

(Date received: 12 July 1999; date accepted: 27 October 1999) 